\title{
SISTEM PENJADWALAN PERKULIAHAN MENGGUNAKAN ALGORITMA GENETIKA (STUDI KASUS PADA JURUSAN TEKNOLOGI INFORMASI FAKULTAS TEKNIK UNIVERSITAS TADULAKO)
}

\author{
D. W. Nugraha1, A. Y. E.Dodu² dan A.T.S. Saud ${ }^{3}$ \\ 1,2,3Program Studi Teknik Informatika Jurusan Teknologi Informasi Fakultas Teknik \\ Universitas Tadulako \\ Jalan Soekarno-Hatta Km. 09 Tondo, Palu 94118, Indonesia \\ 1'deny.wiria.nugraha@gmail.com, 2ayerwin.dodu@gmail.com, 3acipsaud@gmail.com
}

\begin{abstract}
University lecture schedule arranging problem is a problem that requires a lot of time and effort in the process of completion and this problem often faced by the Department of Information Technology Faculty of Engineering, Tadulako University. The purpose of scheduling the courses is how to schedule a few components consisting lecturer, lecture, space, time and classes with certain limitations. To simplify the scheduling process using Genetic Algorithms, that algorithm uses the principle of natural selection in genetics and scheduling optimization process. The algorithm starts by building some combination of population, which consists of chromosomes that contain class, time, space and lecturer, after that the selection process to getting an optimum solution.
\end{abstract}

Keywords : Genetic Algorithm, University Timetabling Scheduling

\section{ABSTRAK}

Permasalahan pengaturan penjadwalan mata kuliah merupakan permasalahan yang membutuhkan banyak waktu dan tenaga dalam proses penyelesaiannya dan masalah ini sering dihadapi oleh Jurusan Teknologi Informasi Fakultas Teknik Universitas Tadulako. Tujuan dari penjadwalan mata kuliah adalah bagaimana cara menjadwalkan sejumlah komponen yang terdiri dari dosen, mata kuliah, ruang, waktu dan kelas dengan batasan-batasan tertentu. Untuk mempermudah proses penjadwalan penulis menggunakan metode Algoritma Genetika, yaitu Algoritma yang menggunakan prinsip genetika dan seleksi alamiah dalam proses optimisasi penjadwalan. Algoritma ini dimulai dengan membangun beberapa kombinasi populasi, yang terdiri dari kromosom-kromosom yang berisi data kelas, waktu, ruangan dan dosen, dan kemudian dilakukan proses seleksi untuk mendapatkan solusi yang optimum.

Kata kunci : Algoritma genetika Penjadwalan perkuliahan 


\section{PENDAHULUAN}

Di dalam proses pelaksanaan perkuliahan, selalu diawali dengan beberapa kegiatan yang dilakukan oleh pihak universitas salah satunya yaitu membuat penjadwalan mata kuliah. Penjadwalan mata kuliah merupakan penjadwalan yang secara rutin dilakukan oleh pihak universitas sebelum memulai proses belajar mengajar.

Perkembangan teknologi informasi banyak memberikan dam pak positif terhadap berbagaihal. Perkembangan tersebut berdampak luas terhadap semua sektor, salah satunya dalam bidang pendidikan. Dalam bidang pendidikan, khususnya pada tingkat universtas, pengolahan data penjadwalan yang cepat, efektif dan efisien sangat dibutuhkan untuk dapat meningkatkan standar mutu pendidikan pada universitas tersebut.

Pada Jurusan Teknologi Informasi Fakultas Teknik Universitas Tadulako proses penjadwalan perkuliahan masih dilakukan secara manual. Dalam penyusunan jadwal sering terjadi benturan antar mata kuliah, dikarenakan jum lah dosen dan ruang pada Jurusan Teknologi Informasi Fakultas Teknik Universitas Tadulako ini terbatas. Hasil penjadwalan perkuliahan yang optimal sangatlah sulit didapatkan apabila dilakukan dengan cara manual, ditambah lagi kondisi ruang dan dosen yang terbatas membuat proses pembuatan jadwal menghabiskan banyak waktu dan tenaga.

Untuk mengatasi permasalahan tersebut, penulis berinisiatif untuk membuat suatu aplikasi yang dapat melakukan penyusunan penjadwalan perkuliahan yang optimal secara otomatis dengan menggunakan pendekatan Algoritma Genetika. Algoritma genetika merupakan algoritma yang berusaha menerapkan pemahaman mengenai evolusi alam iah pada tugas-tugaspemecahanmasalah (problem solving). Pendekatan yang diambil oleh algoritma ini adalah dengan menggabungkansecara acak berbagai pilihan solusi optimal di dalam suatu kumpulan untuk mendapatkan generasi solusi terbaik berikutnya yaitu pada suatu kondisi yang memaksimalkan kecocokannya atau yang disebut dengan fitness.

\section{METODE PENELITIAN}

Penelitian ini merupakan penelitian untuk membuat penjadwalan perkuliahan secara otomatis dimana sebelumnya pada Jurusan Teknologi Informasi Fatek Untad dalam membuat jadwal masih dilakukan secara manual. Metode yang digunakan didalam penelitian ini adalah menggunakan pendekatan Algoritma genetika.

\subsection{Algoritma Genetika}

Algoritma genetika adalah algoritma pencarian yang didasarkan pada mekanisme seleksi alamiah dan genetika alamiah. Pada awalnya algoritma genetika memang digunakan sebagai algoritma pencarian parameter-parameter optimal. Namun dalam perkembangannya, algoritma genetika bisa diaplikasikan untuk berbagai masalah lain seperti pembelajaran, 
peramalan, pemrograman otomatis, dan sebagainya. Pada bidang soft computing, algoritma genetika banyak digunakan untuk mendapatkan nilai-nilai parameter yang optimal pada jaringan syaraf tiruan maupun sistem fuzzy (Suyanto dalam Prasetyo, 2014).

Algoritma genetika adalah optimasi dan teknik pencarian berdasarkan prinsip prinsip genetika dan seleksi alam. Algoritma genetika memungkinkan populasi yang terdiri daribanyak individu untuk dapat berkembang berdasarkan aturan seleksi tertentu ke keadaan fitness maksimal (fungsi biaya minimal). Metode ini dikembangkan oleh John Holland (1975) selama tahun 1960-an dan 1970-an dan akhirnya dipopulerkan oleh salah seorang muridnya, David Goldberg (Haupt dalam Prasetyo, 2014).

Teknik pencarian yang dilakukan oleh algoritma genetika bersamaan dengan solusi yang mungkin yang dikenal dengan istilah populasi. Individu yang terdapat dalam satupopulasi disebut dengan istilah kromosom. Kromosom ini merupakan suatu solusi yang masihberbentuk simbol. Populasi awal dibangun secara acak, sedangkan populasi berikutnya merupakanhasil evolusi kromosom-kromosom melalui proses iterasi yang disebut dengan istilah generasi.Pada setiap generasi, kromosom akan melalui proses evaluasi dengan meng gunakan alatukuryang disebut dengan fungsi fitness. Generasi berikutnya dikenal dengan istilah anak (offspring)yang terbentuk dari gabungan dua kromosom generasi sekarang yang bertindak sebagai induk (parent) dengan menggunakan operator penyilangan, suatu kromosom dapatjuga dimodifikasi dengan menggunakan operator mutasi. Populasi generasi yang baru dibentuk dengan cara menyeleksi nilai fitness dari kromosom induk (parent) dan nilai fitness dari kromosom anak (offspring), serta menolak kromosom-kromosom yang lainnya sehingga ukuran populasi (jumlah kromosom dalam suatu populasi) konstan. Setelah melalui beberapa generasi, maka algoritma ini akan konvergen ke kromosom terbaik.

\subsection{Penjadwalan}

Penjadwalan adalah penempatan sumber daya (resource) dalam satu waktu. Penjadwalan mata kuliah dan ujian akhir semester merupakan persoalan penjadwalan umum dan sulit yang tujuannya adalah menjadwalkan pertemuan dari sumber daya. Sumber daya yang dimaksud adalah dosen pengasuh mata kuliah, mata kuliah, ruang kuliah, kelas mahasiswa, dan waktu perkuliahan (Setemen dalam Sam'ani, 2012). Terdapat batasan/persyaratan pokok (hard constraints) dalam penyusunan penjadwalan mata kuliah. Hard constraint sendiri merupakan suatu syarat tidak boleh terjadi pelanggaran terhadap kendala yang ditetapkan agar dapat menghasilkan susunan penjadwalan yang baik. Jikaterjadi pelanggaran terhadap kendala yang ditetapkan maka akan diberikan suatu nilai penalti atau hukuman antara 0 sampai 1 untuk setiap pelanggaran. Semakin kecil jum lah pelanggaranyang terjadi solusi penjadwalan yang dihasilkan akan semakin baik. 
Selain batasan pokok ( hard constraint) di dalam penjadwalan juga terdatap batasan tambahan penjadwalan (soft constraint). Batasan tambahan penjadwalan adalah batasan ataupun sering disebut batasan khusus penjadwalan adalah aturan-aturan istimewa yang ditambahkan sesuai dengan kondisi tertentu dari variabel-variabel yang akan dijadwalkan. Batasan-batasan ini tidak terlalu dibutuhkan untuk menghasilkan penjadwalan yang layak pakai, tapi apabila aturan pokok tidak cukup untuk menghasilkan penjadwalan yang layak pakai, maka aturan tambahan dapat digunakan sehingga semua variabel yang terlibat tidak diacuhkan. Aturan tambahan penjadwalan memang kadang diperlukan, tapi tetap tidak memungkinkan untuk memasukkan semua aturan tambahan pada aturan pokok penjadwalan.

\subsection{Penjadwalan dengan Algoritma Genetika}

Gambar 1 : memperlihatkan diagram alir algoritma genetika secara umum pada penelitian ini :

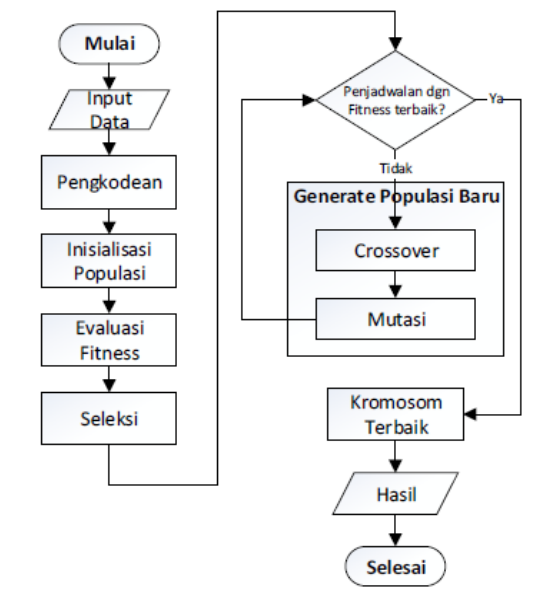

Gambar 1 : FlowchartAlgoritma Genetika

(sumber : Suhartono, 2015)

1. Skema Pengkodean

Teknik pengkodean adalah bagaimana mengkodekan gen dari kromosom. Masingmasing kromosom berisi sejumlah gen yang mengkodekan informasi yang disimpan didalam kromosom. Pada penelitian ini menggunakan teknik pengkodean dalam bentuk string bit/varcharyang dipergunakan dalam pemrograman genetika

2. Menentukan populasi awal dan inisialisasi kromosom

Menentukan populasi awal adalah proses membangkitkan sejumlah kromosom secara acak. Kromosom menyatakan salah satu alternatif solusi yang mungkin. Kromosom dapat dikatakan sama dengan individu. Ukuran populasi tergantung pada masalah yang akan diselesaikan. Setelah ukuran populasi ditentukan, kemudian dilakukan pembangkitan populasi awal dengan cara melakukan inisialisasi solusi yang mungkin kedalam sejumlah kromosom. Panjang satu kromosom ditentukan berdasarkan 
permasalahan yang diteliti.

3. Nilai Fitness

Suatu individu dievaluasi berdasarkan suatu fungsi tertentu sebagai ukuran performansinya. Didalam evolusi alam, individu yang bernilai fitness tinggi yang akan bertahan hidup. Sedangkan individu yang bernilai fitness rendah akan mati.

4. Seleksi Orang Tua

Terdapat beberapa jenis metode seleksi, salaha satunya dengan menggunakan Seleksi roda roulette (roulette whee/ selection) . Metode seleksi roulette-whee/memiliki cara kerja yaitu menirukan permainan roulette-whee/dimana masing-masing kromosom menempati potongan lingkaran pada roulette-whee/secara proporsional sesuai dengan nilai fitnessnya. Kromosom yang memiliki nilai fitnesslebih besar menempati potongan lingkaran yang lebih besar dibandingkan dengan kromosom bernilai fitness rendah.

5. Pindah Silang

Pindah silang (crossover) digunakan sebagai metode pemotongan kromosom secara acak dan merupakan penggabungan bagian pertama dari kromosom induk 1 dengan bagian kedua dari kromoson induk 2 Pindah silang bisa dilakukan hanya jika suatu bilangan acak yang dibangkitkan untuk kromosom kurang dari probabilitas pindah silang (Pc) yang ditentukan. Menurut (Suyanto dalam Sam'ani, 2005) Pc umumnya diset mendekati 1 , misalnya 0,5 .

Metode pindah silang yang paling umum digunakan adalah pindah silang satu titik potong (one-point crossover). Suatu titik potong dipilih secara acak, kemudian bagian pertama dari kromosom induk 1 digabungkan dengan bagian kedua dari kromosom induk 2. Bilangan acak yang dibangkitkan untuk menentukan posisi titik potong adalah [1 $-\mathrm{N}]$ dimana $\mathrm{N}$ merupakan banyaknya jumlah gen dalam satu kromosom

6. Mutasi

Proses mutasi adalah suatu proses kemungkinan memodifikasi informasi gen-gen pada suatu kromosom Perubahan ini dapat membuat solusi duplikasi menjadi memiliki nilai fitnessyang lebih rendah maupun lebih tinggi daripada solusi induknya. Jika temyata diperoleh solusi yang memiliki fitnessyang lebih tinggi maka hal itulah yang diharapkan. Tetapi jika diperoleh solusi dengan nilai fitness yang lebih rendah maka bisa jadi pada iterasi berikutnya diperoleh solusi hasil mutasi yang lebih baik nilai fitnessnya daripada solusi induknya. Untuk semua gen yang ada, jika bilangan acak yang dibangkitkankurang dari probabilitas mutasi (Pmut) yang telah ditentukan maka beberapa informasi gen akan dirubah dengan menggunakan metode pengkodean nilai. Pmutumumnya diset antara[0 - 1], misalnya 0,1 (Suyanto, 2005) 
7. Kriteria Penghentian

Terdapat berbagai macam kriteria penghentian yang bisa digunakan (Prasetyo, 2014), tiga diantaranya adalah:

a. Memberikan batasan jumlah iterasi. Apabila batas iterasi tersebut dicapai, iterasi dihentikan dan laporkan individu bernilai fitness tertinggi sebagai solusi terbaik.

b. Memberikan batasan waktu proses algoritma genetika. Kriteria ini digunakan pada sistem-sistem waktu nyata (real time system), dimana solusi harus ditemukanpaling lama, misalkan 12 jam. Dengan demikian, algoritma genetika bisa dihentikan,ketika proses sudah berlangsung hampir 12 jam.

c. Menghitung kegagalan penggantian anggota populasi yang terjadi secara berurutan sampai jumlah tertentu.

\section{HASIL DAN PEMBAHASAN}

\subsection{Implementasi Sistem}

Sistem penjadwalan perkuliahan menggunakan algoritma genetika diim plementasikan menggunakan perangkat keras dengan spesifikasi processorCore I3, $1,70 \mathrm{GHz}$, RAM $4 \mathrm{~GB}$, Monitor dengan resolusi $1366 \times 768$ dan sistem operasi windows 864 bit. Untuk im plementasi perangkat lunak digunakan bahasapemrograman PHPsebagai media pembuatan dan perancangan sistem, Codelgniteryangmenupakan framework khusus untuk bahasa pemrograman $p h p$ dan MySQL sebagai media penghubung antara bahasa pemrograman dengan database.

\subsection{Pemodelan Sistem}

Jenis pemodelan sistem yang digunakan untuk menggambarkan ruang lingkup sistem mengunakan Diagram Konteks. Berikut merupakan diagram konteks dari sistem penjadwalan mata kuliah ditujukan pada gambar 2 .

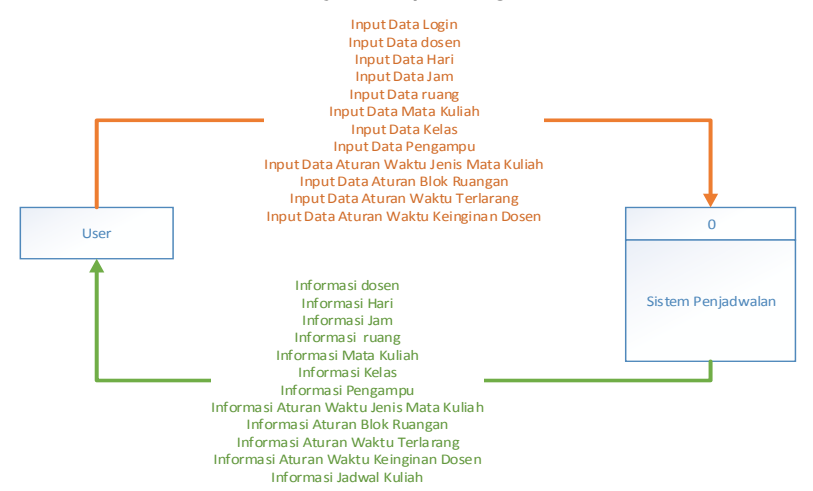

Gambar 2 : Context Diagram Sistem Penjadwalan Perkuliahan

Keterangan gambar 2 dapat dilihat pada penjelasan berikut : 
a. User

User pada aplikasi penjadwalan memiliki fungsi untuk mengirim input dan menerima hasil output dari sistem. Inputyang dikirimkan oleh userberupa data-data yang digunakan dalam penjadwalan seperti data mata kuliah, data ruangan, data waktu dan sebagainya. Kemudian sistem akan merespon dengan mengirimkan outputkepada user berupa data-data yang berkaitan dengan penjadwalan.

b. Sistem Penjadwalan

Sistem Penjadwalan mengolah data-data yang dimasukan oleh user menjadi sebuah informasi yang berhubungan dengan penjadwalan seperti informasi jadwal, informasi kelas dan lain-lain.

\subsection{Perancangan Sistem}

Pada perancangan sistem ini akan diimplementasikan menggunakan algoritma genetika yang terdiri dari beberapa tahapan yang lebih spesifik seperti perancangan pembangkitan kromosom, perancangan metode pembangkitan populasi, perancangan nilai fitnessindividu, perancangan metode seleksi, perancangan metode kawin silang (crossover), perancangan metode mutasi, dan perancangan update generasi.

1. Perancangan Pembangkitan Kromosom

Pada penelitian tentang penjadwalan ini solusi yang akan dihasilkan adalah menentukan waktu dan ruang untuk perkuliahan. Panjang satu kromosom adalah gabungan gen berdasarkan jumlah dari seluruh mata kuliah dan kelas yang ditawarkan pada semester aktif. Satu gen berisi informasi pengampu, waktu dan ruang. Sebagai contoh untuk inisialisasi pembentukan kromosom.

Tabel 1 : Tabel Pengampu

\begin{tabular}{|c|l|c|c|c|c|}
\hline $\begin{array}{c}\text { Kode } \\
\text { Pengampu }\end{array}$ & Nama Dosen & Nama Mata Kuliah & Kelas & $\begin{array}{c}\text { Tahun } \\
\text { Ajaran }\end{array}$ & Peminat \\
\hline P1 & Deny W. N & Kriptografi & A & $2017 / 2018$ & 50 \\
\hline P2 & A. Y. Erwin & Pengenalan Pola & A & $2017 / 2018$ & 50 \\
\hline P3 & A. Y. Erwin & Pengenalan Pola & B & $2017 / 2018$ & 15 \\
\hline P4 & Dessy Santi & Computer Vision & A & $2017 / 2018$ & 15 \\
\hline
\end{tabular}

Tabel 2 : Tabel Jam Mata Kuliah

\begin{tabular}{|c|c|}
\hline Kode Jam & Waktu \\
\hline T1 & $08.00-08.50$ \\
\hline T2 & $08.50-09.30$ \\
\hline T3 & $09.30-10.20$ \\
\hline T4 & $10.20-11.10$ \\
\hline
\end{tabular}


Tabel 3 : Tabel Hari

\begin{tabular}{|c|c|}
\hline Kode Jam & Waktu \\
\hline $\mathrm{H} 1$ & Senin \\
\hline $\mathrm{H} 2$ & Selasa \\
\hline $\mathrm{H} 3$ & Rabu \\
\hline $\mathrm{H} 4$ & Kamis \\
\hline
\end{tabular}

Tabel 4 : Tabel Ruang

\begin{tabular}{|c|c|c|}
\hline Kode Ruang & Nama Ruang & Kapasitas \\
\hline R1 & KDK_RPL & 20 \\
\hline R2 & TI & 60 \\
\hline R3 & KDK_SC & 20 \\
\hline R4 & IO & 50 \\
\hline
\end{tabular}

Tabel 5 : Tabel Waktu Dosen Tidak Bersedia Mengajar

\begin{tabular}{|c|c|c|}
\hline Nama Dosen & Hari & Waktu \\
\hline Dessy Santi & Selasa & $08.00-08.50$ \\
\hline
\end{tabular}

Diasumsikan satu populasi yang terbentuk berjumlah 4 kromosom sesuai dengan table pengampu yang ada masing-masing kromosom memiliki 4 gen.

Tabel 6 : Tabel Pembentukan Kromosom

\begin{tabular}{|c|c|c|c|c|}
\hline & Gen 1 & Gen 2 & Gen 3 & Gen 4 \\
\hline Kromosom 1 & P1 T1 H1 R2 & P2 T3 H1 R2 & P3 T3 H1 R2 & P4 T1 H1 R2 \\
\hline Kromosom 2 & P1 T1 H1 R2 & P2 T3 H1 R2 & P3 T3 H1 R3 & P4 T1 H2 R3 \\
\hline Kromosom 3 & P1 T1 H1 R2 & P2 T3 H1 R1 & P3 T3 H1 R1 & P4 T3 H2 R1 \\
\hline Kromosom 4 & P1 T1 H1 R2 & P2 T3 H1 R2 & P3 T1 H2 R1 & P4 T1 H3 R3 \\
\hline
\end{tabular}

Urutan kode pada setiap gen mewakili kode pengampu kelas, kode waktu, kode hari, dan kode ruang. Penempatan urutan kode pada setiap gen dilakukan secara acak berdasarkan suatu bilangan yang dibangkitkan secara acak pula.

2. Perancangan Nilai Fitness Individu

Nilai fitness pada individu menggunakan nilai antara 0 dan 1, Nilai yang dihasilkan oleh fungsi fitness merepresentasikan seberapa banyak jumlah persyaratan yang dilanggar, sehingga dalam kasus penjadwalan perkuliahan semakin kecil jumlah pelanggaran yang dihasilkan maka solusi yang dihasilkan 
akan semakin baik. Untuk setiap pelanggaran yang terjadi akan dib erikan nilai 1 . Agar tidak terjadi nilai fitness yang tak terhingga maka jumlah total semua pelanggaran akan ditambahkan 1.

$$
F=\frac{1}{1+\sum B R W+\sum B D+\sum B K A S+\sum B K E S}
$$

Keterangan :

BRW : Bentrok ruang dan waktu

BD : Bentrok dosen

BKAS : Bentrok kapasitas kelas

BKES : Bentrok kesediaan waktu dosen

3. Perancangan Metode Seleksi

Pada penelitian ini digunakan seleksi rangking dalam menyeleksi orang tua yang akan dikawinkan dari kromosom-kromosom yang berada pada populasi dengan menggunakan nilai fitnessyang telah didapatkan. Jumlah kromosomyang dihasilkan dari hasil seleksi adalah sebanyak jumlah kromosom.

4. Perancangan Metode Perkawinan Silang

Metode perkawinan silang (crossover) yang digunakan adalah metode $n$ point crossover dengan 2 titik (2-point crossover) menggunakan probabilitas $p c$. Pertama kromosom yang telah terseleksi masing-masing dibangkitkan nilai random yang kemudian dibandingkan dengan $p c$. Apabila nilainya kurangdariatau sama dengan $p c$, maka kromosom tersebut ditandai sebagai parent. Setelah parent didapatkan, kemudian dicari 2 titik potong kromosom secara acak dari indeks gen 2 hingga $n-1$. Masing-masing parent dibuat berpasangan secara sekuensial (parent $\mathrm{A}$ dan parent $\mathrm{B}$, parent $\mathrm{B}$ dan parent $\mathrm{C}$, parent $\mathrm{C}$ dan parent $\mathrm{D}$, dan seterusnya) yang kemudian dikawinkan silang menggunakan 2-point crossover berdasarkan titik potong yang telah didapatkan hingga akhirnya didapatkan offspring. Contoh rancangan crossover dengan titik potong a $=2$ dan $\mathrm{b}=5$ ditunjukan pada gambar 3 . 


\begin{tabular}{|c|c|c|c|c|c|c|c|c|}
\hline \multicolumn{10}{|c|}{$\mathrm{a}=2$ dan $\mathrm{b}=5$} \\
\hline \multirow{2}{*}{ Parent 1 } & id Kelas & 1 & 2 & 3 & 4 & 5 & $\ldots$ & $\mathrm{m}$ \\
\cline { 2 - 10 } & id ruang waktu & 23 & 47 & 59 & 70 & 63 & $\ldots$ & 80 \\
\hline \multirow{2}{*}{ Parent 2 } & id Kelas & 1 & 2 & 3 & 4 & 5 & $\ldots$ & $\mathrm{m}$ \\
\cline { 2 - 10 } & id ruang waktu & 11 & 13 & 80 & 89 & 90 & $\ldots$ & 102 \\
\hline \multirow{2}{*}{ Offspring 1 } & id Kelas & 1 & 2 & 3 & 4 & 5 & $\ldots$ & $\mathrm{m}$ \\
\cline { 2 - 10 } & id ruang waktu & 23 & 47 & 59 & 70 & 63 & $\ldots$ & 80 \\
\hline \multicolumn{7}{|c|}{} \\
\hline \multirow{2}{*}{ Offspring 2 } & id Kelas & 1 & 2 & 3 & 4 & 5 & $\ldots$ & $\mathrm{m}$ \\
\cline { 2 - 10 } & id ruang waktu & 11 & 13 & 80 & 89 & 90 & $\ldots$ & 102 \\
\hline
\end{tabular}

Gambar 3 : Contoh proses kawin silang

\section{Perancangan Metode Mutasi}

Pada proses mutasi ini menggunakan kromosom offspring yang dihasilkan dari proses crossover. Pertama membangkitkan nilai acak dari masing-masing kromosom yang nilainya 1 atau 0 yang kemudian dibandingkan dengan $P m$, apabilai nilainya lebih kecil dari $P m$ maka kromosom offspring tersebutmengalami mutasi. Metode mutasi menggunakan mutasi pada pengkodean nilai, yakni mengganti bagian gen yang posisinya didapatkan secara acak dengan indeks waktu ruang yang belum digunakan. Setelah kromosom offspring mengalami mutasi, kemudian dilakukan pengecekan kembali terhadap aturan umum. Jika terjadi pelanggaran terhadap aturan umum maka indeks ruang waktu diganti dengan indeks yang belum digunakan hingga didapatkan kromosom yang layak. Kemudian masing-masing offspring dihitung fitness-nya kembali untuk penilaian kualitasnya. Contoh rancangan mutasi ditunjukan pada gambar 4 .

\begin{tabular}{|l|c|c|c|c|c|c|c|c|}
\hline \multirow{2}{*}{ Kromosom 1 } & id Kelas & 1 & 2 & 3 & 4 & 5 & $\ldots$ & $\mathrm{m}$ \\
\cline { 2 - 9 } & id ruang waktu & 23 & 47 & 59 & 70 & 63 & $\ldots$ & 80 \\
\hline \multirow{2}{*}{ Kromosom 1} & id Kelas & 1 & 2 & 3 & 4 & 5 & $\ldots$ & $\mathrm{m}$ \\
\cline { 2 - 9 } & id ruang waktu & 23 & 47 & 50 & 70 & 63 & $\ldots$ & 80 \\
\hline
\end{tabular}

Gambar 4 : Contoh Proses Mutasi

\section{Perancangan Update Generasi}

Pada proses updategenerasi dilakukan penggabungan kromosom offspring, hasil proses mutasi dan kromosom hasil seleksi sebelumnya

\subsection{Pengujian Sistem}

Pengujian terbagi menjadi dua jenis, yaitu pengujian fungsi sistem dan pengujian algoritma genetika untuk penjadwalan. Pengujian ini memungkinkan analis sistem memperoleh kumpulan kondisi input yang akan mengerjakan seluruh keperluan 
fungsional program. pengujian fungsi sistem dilakukan dengan menggunakan jenis pengujian black-box. Berikut ini merupakan hasil dari pengujian yang dilakukan :

1. Pengujian Fungsi Sistem

Tabel 7 : Pengujian Fungsi Sistem

\begin{tabular}{|l|l|c|}
\hline Fungsi Yang Diuji & \multicolumn{1}{|c|}{ Ekspetasi Hasil } & $\begin{array}{c}\text { Hasil } \\
\text { Pengujian }\end{array}$ \\
\hline Login & $\begin{array}{l}\text { Dapat melakukan verifikasi login yaitu } \\
\text { jika username dan password yang } \\
\text { diinputkan benar maka user dapat } \\
\text { masuk ke menu utama dan jika salah } \\
\text { akan muncul pesan untuk melakukan } \\
\text { login kembali }\end{array}$ & \\
\hline Pengolahan Data & $\begin{array}{l}\text { Dapatmelakukan penambahan data, } \\
\text { edit data, hapus data, pencarian data } \\
\text { dan melihat data yang telah diinputkan }\end{array}$ & Berhasil \\
\hline Pembuatan Jadwal & $\begin{array}{l}\text { Dapatmelakukan penambahan kelas, } \\
\text { pengisian dosen pengampu }\end{array}$ & Berhasil \\
& menentukan softconstraint & \\
\hline
\end{tabular}

Dari hasil pengujian pada tabel 7 dapat disimpulkan bahwa proses login, pengolahan data dan pembuatan jadwal dapat berjalan sesuai dengan yang diharapkan.

2. Pengujian Algoritma Genetika

Dari hasil pengujian algoritma genetika untuk penjadwalan perkuliahan didapatkan hasil sebagai berikut :

Tabel 8 : Nilai Parameter Algoritma Genetika

\begin{tabular}{|c|c|}
\hline Operator & Nilai \\
\hline Jumlah Kromosom & 60 \\
\hline Probabilitas Penyilangan & 0.6 \\
\hline Probabilitas Mutasi & 0.4 \\
\hline Jumlah Generasi & 5000 \\
\hline
\end{tabular}


Tabel 9. Hasil Proses Genetika

\begin{tabular}{|c|c|}
\hline Deskripsi & Nilai \\
\hline Generasi Terbaik & 2127 \\
\hline Populasi Terbaik & 56 \\
\hline Nilai Fltnes & 1 \\
\hline Waktu Komputasi & 23972.641 (6 Jam 36 Menit) \\
\hline
\end{tabular}

Tabel 10. Daftar Jumlah Benturan Jadwal

\begin{tabular}{|c|c|}
\hline Daftar Benturan & Nilai \\
\hline Kapaistas Ruangan & 0 \\
\hline Paket Semester & 0 \\
\hline Waktu Larangan & 0 \\
\hline Waktu Tidak Sesuai Keinginan Dosen & 0 \\
\hline Blok Semester Tidak Sesuai & 0 \\
\hline Rua Waktu Sama Pengampu Beda & 0 \\
\hline Dosen Waktu Sama Pengampu Beda & 0 \\
\hline Jenis Mata Kuliah Waktunya Tidak Sesuai & 0 \\
\hline
\end{tabular}

Berikut merupakan jadwal perkuliahan yang dihasilkan dari proses Algoritma Genetika :

\begin{tabular}{|c|c|c|c|c|c|c|c|}
\hline \multicolumn{8}{|c|}{$\begin{array}{c}\text { KEMENTRIAN RISET, TEKNOLOGI DAN PENDIDIKAN TINGGI } \\
\text { UNIVERSITAS TADULAKO } \\
\text { FAKULTAS TEKNIK } \\
\text { JURUSAN TEKNOLOGI INFORMASI } \\
\text { Kampus Bumi Tadulako Tondo Palu - Sulawesi Tengah } 94111 \\
\text { J. Soekarno Hatta Km. 9, Telp : (0451) 45014, 422611, Fax. : (0451) } 454014 \\
\text { Email : untad@untad.ac.id }\end{array}$} \\
\hline \multicolumn{4}{|c|}{$\begin{array}{l}\text { JADWAL KULAH : SEMESTER } 2 \\
\text { TAHUN AKADEMIK : 2016-2017 } \\
\text { KELAS } \\
\text { : A }\end{array}$} & \multicolumn{4}{|c|}{$\begin{array}{l}\text { JURUSAN : TEKNOLOGI INFORMASI } \\
\text { PROGRAM STUDI : TEKNIK INFORMATIKA (SI) }\end{array}$} \\
\hline No & $\begin{array}{c}\text { KODE } \\
\text { MАККПМА } \\
\end{array}$ & 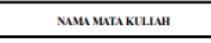 & sks & NMMAOSEX & HARI & мам & Retung \\
\hline 1 & DU 69201 & Pendidikm Agama Islam & 2 & $\begin{array}{l}\text { Dosen Agama } 1 \\
\text { Dosen Agama } 2 \\
\end{array}$ & Jumat & $08.00 \cdot 09.40$ & 6 \\
\hline 2 & DU69202 & Kalkulus II & 3 & $\begin{array}{c}\text { Andi Hendra, SSi, M.Kom. } \\
\text { Syaiful Hendra, S. Kom, M.Kom. } \\
\end{array}$ & Selasa & $09,40 \cdot 12,10$ & 5 \\
\hline 3 & DU69203 & Pendidikan Karakiter dan Anti Korupsi & 2 & 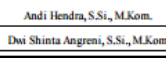 & Rabu & $08.00 \cdot 09.40$ & 8 \\
\hline 4 & П69201 & Probabilitas dan Statistik & 2 & 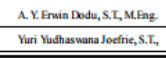 & Jumat & $14,40 \cdot 1620$ & 5 \\
\hline 5 & 1 69202 & Struiktur Data & 3 & $\begin{array}{c}\text { Amriana, S.T, M.I. } \\
\text { Chairunisa Lanusitudju, S.Kom. }\end{array}$ & Rabu & 11.20 .13 .50 & 5 \\
\hline 6 & $\mathrm{n} 69203$ & Praktikum Srrultur Data & 1 & Asisten Prakitikum & Jumat & $09,40 \cdot 11.20$ & 7 \\
\hline 7 & n69204 & Interaksi Manusia Komputer & 2 & $\begin{array}{c}\text { Deny Wiria Nugraha, S.T.M.Mn } \\
\text { Wirdayanti, S.T, M.Fng. } \\
\end{array}$ & Rabu & $1530 \cdot 17.10$ & 6 \\
\hline 8 & n69205 & Praktikikum Interaksi Manusia Komputer & 1 & Asisten Praktikum & Selasa & $14,40 \cdot 16.20$ & 8 \\
\hline 9 & 1169206 & Sistem Digital & 2 & $\begin{array}{l}\text { Yusuf Anshori, S.T, M.T. } \\
\text { Rizana Fauri, S.T, M.T. } \\
\end{array}$ & Kamis & $15,30 \cdot 17.10$ & 8 \\
\hline 10 & T169207 & Praktikum Sistem Digital & 1 & Asisten Praktikum & Rabu & $1350 \cdot 15.30$ & 6 \\
\hline
\end{tabular}

Gambar 5 : Hasil Jadwal Kuliah Semester 2 Kelas A 


\section{KESIMPULAN}

Berdasarkan pengujian dan analisis sistem penjadwalan perkuliahan, maka dapat diambil kesimpulan sebagai berikut :

1. Pada penelitian ini proses penjadwalan perkuliahan menggunakan algoritma genetika dimulai dari proses pembangkitan kromosom, kemudian pembentukan populasi, setelah itu dilakukan pengecekan nilai fitness pada masing-masing kromosom, setelah nilai fitness didapatkan kemudian dilakukan seleksi. Kromosom yang telah terseleksi masing-masing dibangkitkannilai random untuk dilakukan proses crossover. hasil yang didapatkan dari proses crossover kemudian dilakukan mutasi. Setelah itu 1 langkah terakhir dari algoritma ini yaitu dilakukan penggabungan kromosom offspring, hasil proses mutasi dan kromosom hasil seleksi sebelumnya.

2. Sistem Penjadwalan dijalankan dengan memasukan data input berupa 25 dosen, 45 mata kuliah, 10 ruang pada semester genap tahun ajaran 2016/2017. Fitnes terbaik didapat pada generasi 2127 dengan waktu komputasi selama 6 jam 36 menit. Dari hasil proses algoritma maka didapatkan suatu penjadwalan yang optimal karena tidak terdapat jadwal yang konflik.

3. Parameter algoritma yang digunakan pada penelitian ini yaitu menggunakan nilai probabilitas pindah silang 0.6 , probailitas mutasi 0.4 , jum lah kromosom 60 dan jum lah generasi sebanyak 5000 .

4. Pada perancangan algoritma, jenis seleksi yang digunakan adalah metode seleksi peringkat. Metode ini memberikan perubahan nilai fitness pada seluruh kromosom menjadi baik secara merata.

5. Pada penelitian ini digunakan 2 titik potong penyilangan. Dalam metode ini kromosom anak pertama dihasilkan dari sisa potongan induk pertama dan hasil potongan dari induk ke dua. Sebaliknya, induk kromosom anak kedua dihasilkan dari sisa potongan induk kedua dan hasil potongan dari induk pertama.

6. Pada proses penjadwalan, semakin banyak kelas yang dijadwalkan maka semakin lamawaktu yang dibutuhkan oleh algoritma genetika dalam menghasilkan jadwal. 


\section{DAFTAR PUSTAKA}

[1] Prasetyo, E.B, Penerapan Algoritma Genetika dan Jaringan Syaraf Tiruan dalam Penjadwalan Mata Kuliah di Fakultas Matematika dan IImu Pengetahuan Alam Universitas Gadjah Mada. Skripsi, 2014, Universitas Gajah Mada, Yogyakarta.

[2] Sam'ani, S, Rancang Bangun Sistem Penjadwalan Perkuliahan dan Ujian Akhir Semester Dengan Pendekatan Algoritma Genetika. Tesis, 2014, Universitas Diponogoro, Semarang.

[3] Sedarmayanti \& Syarifudin Hidayat, Metodologi Penelitian, Mandar Maju, 2002, Bandung.

[4] Suhartono, E, Optimasi Penjadwalan Mata Kuliah dengan Algoritma Genetika. INFOKAM Nomor II, 2005, AMIK JTC, Semarang.

[5] Suyanto, Artificial Intelegent(Searching, Reasoning, Planning, Learning), Edisi Revisi, Penerbit Informatika, 2004, Bandung. 